\title{
A Puzzle about Logical Analysis
}

\section{Stefan Rinner ${ }^{1}$ (i)}

Received: 15 February 2021 / Revised: 4 July 2021 / Accepted: 12 July 2021 /

Published online: 13 August 2021

(C) The Author(s) 2021

\section{Abstract}

In this paper, I will present a puzzle for logical analyses, such as Russell's analysis of definite descriptions and Recanati's analysis of 'that'-clauses. I will argue that together with Kripke's disquotational principles connecting sincere assent and belief such non-trivial logical analyses lead to contradictions. Following this, I will compare the puzzle about logical analysis with Frege's puzzle about belief ascriptions. We will see that although the two puzzles do have similarities, the solutions to Frege's puzzle cannot be applied mutatis mutandis to the puzzle about logical analysis. Hence, to say it with Kripke, the main thesis of this paper is that the puzzle is a puzzle. A complete solution to the puzzle promises a better understanding of both logical analyses and belief ascriptions.

Keywords Logical analysis · Definite description $\cdot$ Belief $\cdot$ Frege's puzzle

\section{Introduction}

In "On Denoting", Bertrand Russell (1905) famously argues that sentences containing definite descriptions, such as (1), have subject-predicate structure only on the surface.

(1) The first man on the Moon is American.

For Russell, the real logical form of (1) is made explicit in (2). ${ }^{1}$

\footnotetext{
${ }^{1}$ Here I am using Neale's (1990) variant of Russell's theory of definite descriptions. According to Russell's original analysis, (1) has to be analysed as 'There is one and only one first man on the Moon and something that is first man on the moon is American'. Since Neale's variant retains Russell's truth-conditions, this does not affect the main thesis of this paper.
}

$\triangle$ Stefan Rinner

stefan.rinner@uni-hamburg.de

1 University of Hamburg, Hamburg, Germany 
(2) There is one and only one first man on the Moon and every first man on the moon is American.

Making the real logical structure or form of a sentence explicit in this way is often called a 'logical analysis'. Another example is Recanati's (2004) analysis of 'that'-clauses as restricted existential quantifiers. Following Panaccio (1996, 266-7), Recanati analyses (3) as (4), i.e. '[ $\exists p$ : TRUE (p) iff WHITE (show)] BELIEVES (Nixon, $p$ )', where $p$ ranges over truth-bearing entities.

(3) Nixon believes that snow is white.

(4) Nixon believes something that is true iff snow is white.

Providing analyses like this is not only of importance for logic and philosophy of language, but, as Russell (1905) has shown, can have implications for other areas of philosophy, such as metaphysics and epistemology.

In this paper, I will present a puzzle for logical analyses, such as Russell's analysis of definite descriptions and Recanati's analysis of 'that'-clauses. I will argue that together with Kripke's disquotational principles connecting sincere assent and belief such non-trivial logical analyses lead to contradictions. Following this, I will compare the puzzle about logical analysis with Frege's puzzle about belief ascriptions. We will see that although the two puzzles do have similarities, the solutions to Frege's puzzle cannot be applied mutatis mutandis to the puzzle about logical analysis. Hence, to say it with Kripke, the main thesis of this paper is that the puzzle is a puzzle. A complete solution to the puzzle promises a better understanding of both logical analyses and belief ascriptions.

\section{The Puzzle}

The starting point of the puzzle are Kripke's disquotational principles connecting sincere assent and belief. For example, Kripke (1979) points out that from a sincere and reflective utterance of 'Cicero was a Roman orator' we usually infer that the speaker believes that Cicero was a Roman orator. Similarly, if a normal English speaker is, on reflection, not disposed to sincerely and reflectively utter 'Cicero was a Roman orator', we infer that the speaker does not believe that Cicero was a Roman orator. Thus, according to Kripke, in everyday life, we presuppose the following disquotational principles connecting sincere assertion and belief, where ' $p$ ' can be replaced, inside and outside quotation marks, by any standard English sentence lacking indexical or pronominal devices or ambiguities (Kripke 1979, 248-9): ${ }^{2}$

$(D P)$ If a normal English speaker is disposed to sincerely and reflectively utter ' $p$ ', then he/she believes that $p$.

\footnotetext{
${ }^{2}$ Sentences containing indexical or pronominal devices are excluded, since, for example, from Ralph's sincere, reflective utterance of 'I am hungry' it does not follow that he believes that I (the author) am hungry (Kripke 1979, 249).
} 
$(R D P) \quad$ If a normal English speaker, who is not reticent, is not disposed to sincerely and reflectively utter ' $p$ ', then he/she does not believe that $p$.

Analogous principles can be formulated for French, German etc.

Taken in their obvious intent, $(D P)$ and $(R D P)$ seem to be self-evident truths. However, together with non-trivial logical analyses, such as Recanati's analysis of 'that'-clauses and Russell's analysis of definite descriptions, these two principles lead to contradictions. Take, for example, the great philosopher David Lewis. Lewis was a normal English speaker who was certainly disposed to sincerely and reflectively utter (3). Together with $(D P)$, it follows that (5) is true.

(5) Lewis believed that Nixon believes that snow is white.

Since, according to Recanati's analysis, 'that'-clauses are restricted quantifiers, from this, in turn, it follows that (6) is true.

(6) Lewis believed that Nixon believes something that is true iff snow is white.

However, since Lewis (1979) did not believe that belief is a relation holding between agents and truth-bearing entities, ${ }^{3}$ he was certainly not disposed to sincerely and reflectively utter (4). Together with $(R D P)$, it follows that in addition to (6) also (7) is true.

(7) Lewis did not believe that Nixon believes something that is true iff snow is white.

Thus, together with plausible assumptions, Kripke's disquotational principles and Recanati's analysis of 'that'-clauses lead to contradictions.

A similar problem arises in connection with Russell's analysis of definite descriptions. For example, since Strawson (1950) believed that sentences containing empty definite descriptions lack truth-values, he was certainly not disposed to sincerely and reflectively utter (8), even if the description takes narrow scope with respect to the negation operator. 4

(8) It is not the case that the first man on Mars is American.

Together with $(R D P)$, it follows that (9) is true.

(9) Strawson did not believe that it is not the case that the first man on Mars is American.

If (9) is true, then, according to Russell's analysis of definite descriptions, so is (10).

\footnotetext{
${ }^{3}$ Instead he believed that belief is a relation holding between agents and properties, such as the property of being in a world where snow is white.

${ }^{4}$ In fact, since, according to Strawson, sentences containing empty definite descriptions lack truth-values, for him the narrow-scope reading of $(8)$, i.e. $\left(8^{\prime}\right)$, is true if and only if its wide-scope reading $\left(8^{\prime \prime}\right)$ is true.

$\left(8^{\prime}\right)$ The following is not the case: The first man on Mars is American.

$\left(8^{\prime \prime}\right)$ For the first man on Mars it holds: It is not the case that he is American.
} 
(10) Strawson did not believe that it is not the case that there is one and only one first man on Mars and that every first man on Mars is American.

However, at the same time, Strawson was certainly disposed to sincerely and reflectively utter (11).

(11) It is not the case that there is one and only one first man on Mars and that every first man on Mars is American.

Together with $(D P)$, it follows that (12) is true.

(12) Strawson believed that it is not the case that there is one and only one first man on Mars and that every first man on Mars is American.

Hence, together with Kripke's disquotational principles connecting sincere assertion and belief, even Russell's analysis of definite descriptions leads to contradictions. It is very likely that similar instances of the puzzle can be construed using other logical analyses that have been proposed in the literature. As long as these analyses aren't trivial, there certainly were philosophers, and thus normal speakers, who have contested them.

The puzzle about logical analysis has obvious similarities with Frege's puzzle about belief ascriptions. For example, since a normal English speaker, such as Sally, could be disposed to sincerely utter 'Cicero was a Roman orator' without being disposed to sincerely utter 'Tully was a Roman orator', according to Kripke's disquotational principles, there can be circumstances in which both (13) and (14) are true.

(13) Sally believes that Cicero was a Roman orator.

(14) Sally does not believe that Tully was a Roman orator.

For Fregeans, this shows that names cannot be substituted salva veritate in belief ascriptions, such as (13) and (14). Millians, on the other hand, reject one of Kripke's disquotational principles in order to solve Frege's puzzle. ${ }^{5}$ Following Kripke's (1980) "Naming and Necessity", these philosophers hold that names (and other singular terms) are directly referential terms, i.e. that the semantic content of a name is just its referent. Thus, according to Millians, if (13) is true, then so is (15). ${ }^{6}$

(15) Sally believes that Tully was a Roman orator.

This suggests that Fregeans and Millians would solve the puzzle about logical analysis differently. Since Fregeans accept both $(D P)$ and $(R D P)$, they have to block the steps from (5) to (6) and from (9) to (10), respectively. Millians, on the other

\footnotetext{
${ }^{5}$ Standardly, Millians reject ( $\left.R D P\right)$. See, for example, Salmon (1986) and Braun (1998).

${ }^{6}$ Not all Millians accept this claim. For example, Millians such as Crimmins and Perry (1989) and Crimmins (1992) hold that names cannot be substituted salva veritate in belief ascriptions by referring to unarticulated constituents. Thus, these philosophers would accept something along the lines of Kripke's disquotational principles.
} 
hand, would block the steps to (5) or (7) and to (9) or (12) by rejecting the respective instances of $(D P)$ or $(R D P)$. Let us, therefore, take a closer look at these two solutions, starting with the Fregean solution.

\section{The Possible Solutions}

For Fregeans, blocking the step from (13) to (15) is compatible with the fact that names can be substituted salva veritate in simple sentences, such as 'Cicero was a Roman orator'. Similarly, Fregeans could try to block the steps from (5) to (6) and from (9) to (10) by claiming that the analyses cannot be applied if the respective sentences are embedded in attitude ascriptions such as (5) and (9). However, such a solution to the puzzle about logical analysis would, among others, significantly weaken Russell's analysis of definite descriptions. For example, Russell famously analysed (16) as (17) in order to explain that (16) can be true without attributing an interest in the law of identity to the first gentleman of Europe in Russell's time.

(16) George IV. wished to know whether Scott was the author of Waverley.

(17) George IV. wished to know whether one and only one man wrote Waverley and Scott was that man.

Hence, for Russell, his analysis does not stop at attitude ascriptions, and if it did, it would have to be supplemented by an analysis of definite descriptions in such contexts. The same holds for Recanati's analysis of 'that'-clauses. If 'that'-clauses are restricted quantifiers, then this should also hold for 'that'-clauses embedded in iterated belief ascriptions. Otherwise, in addition to an analysis of 'that'-clauses in non-iterated belief ascriptions, an advocate of Recanati's analysis would have to provide an analysis of 'that'-clauses embedded in iterated belief ascriptions.

It could be pointed out that Fregeans would reject Recanati's analysis of 'that'clauses and Russell's analysis of definite descriptions altogether. After all, they neither believe that 'that'-clauses are restricted quantifiers nor that definite descriptions have to be analysed in line with Russell's analysis. However, Fregeans have proposed other non-trivial logical analyses. For example, Kaplan (1968) analyses (18) as (19) within a Fregean theory of meaning. ${ }^{7}$

(18) Nine is believed by Hegel to be greater than five.

(19) $\exists s(\mathrm{D}(s$, nine $) \&$ Hegel $\mathbf{B}\ulcorner s$ is greater than five $\urcorner)$.

Since there are normal English speakers who are disposed to accept (18) without being disposed to accept (19), e.g. Millians, together with Kripke's disquotational principles, Kaplan's analysis leads to similar problems as Recanati's analysis of 'that'-clauses and Russell's analysis of definite descriptions. Hence, even for

\footnotetext{
${ }^{7}$ Here the existential quantifier ranges over Fregean senses, ' $D$ ' is a denotational predicate, 'B' stands for the two-place belief relation, and $\ulcorner s$ is greater than five $\urcorner$ denotes a Fregean thought.
} 
Fregeans the solution to the puzzle about logical analysis cannot simply be to reject logical analyses altogether.

Fregeans aren't the only philosophers who have advocated non-trivial logical analyses while accepting Kripke's disquotational principles. For example, since Russell introduced his analysis of definite descriptions, among others, to explain why definite descriptions and ordinary proper names cannot be substituted salva veritate in attitude ascriptions, he would certainly accept something along the lines of $(D P)$ and $(R D P)$. Therefore, even Russell himself would have to block the step from (9) to (10), which, as we have seen above, comes close to abandoning his theory.

We see that for Fregeans and Russell the puzzle about logical analysis is real. First, these philosophers cannot block the steps to (9) and (12), since they accept both (DP) and $(R D P)$. In addition, they want their analyses to apply to attitude ascriptions, such as (9) and (16), as well. In the case of Russell's theory of definite descriptions, nowadays most advocates of the theory no longer accept Russell's claim that proper names stand for definite descriptions. This is why these philosophers usually opt for a Millian solution to Frege's puzzle and, thus, would reject one of Kripke's disquotational principles. Since $(D P)$ seems to be a self-evident truth, Millians usually reject $(R D P) .{ }^{8}$ However, in connection with the puzzle about logical analysis, this is problematic as well.

Take again David Lewis. There certainly are instances of the disquotational principle for truth ' ' $A$ believes that $S$ ' is true iff $A$ believes that $S$ ' such that Lewis was disposed to sincerely and reflectively utter them. For example, Lewis most certainly was disposed to sincerely and reflectively utter " Nixon believes that snow is white' is true iff Nixon believes that snow is white'. Together with $(D P)$, it follows that (20) is true.

(20) Lewis believed that 'Nixon believes that snow is white' is true iff Nixon believes that snow is white.

From this, in turn, it follows together with Recanati's analysis of that-clauses that (21) is true.

(21) Lewis believed that 'Nixon believes that snow is white' is true iff Nixon believes something that is true iff snow is white.

Now, as a leading philosopher and logician, Lewis should have been able to infer from this belief that 'believe' expresses a two-place relation holding between agents and truth-bearing entities. However, as we have seen above, Lewis did not believe such a thing. Instead, he believed that 'believe' expresses a two-place relation holding between agents and properties.

A similar problem arises again in connection with Russell's analysis of definite descriptions. For example, as a normal English speaker, Strawson was certainly disposed to sincerely and reflectively utter " It is not the case that the first man on Mars is American' is true if and only if it is not the case that the first man on Mars is American'. Together with ( $D P$ ), it follows that (22) is true.

\footnotetext{
${ }^{8}$ Salmon (2011) even argues that (DP) is virtually analytic.
} 
(22) Strawson believed that 'It is not the case that the first man on Mars is American' is true if and only if it is not the case that the first man on Mars is American.

Together with Russell's analysis of definite descriptions, we then get:

(23) Strawson believed that 'It is not the case that the first man on Mars is American' is true if and only if it is not the case that there is one and only one first man on Mars and that every first man on Mars is American.

However, since Strawson believed that sentences containing empty definite descriptions lack truth-values, he certainly did not believe that 'It is not the case that the first man on Mars is American' is true if humans have never set foot on Mars.

It is very likely that the two puzzles about logical analysis presented in this paper are just two versions of one and the same puzzle. In this case, the solution to the puzzle cannot simply be to reject $(R D P)$. Since $(D P)$ seems to be a self-evident truth, we are left with two options: $(i)$ rejecting non-trivial logical analyses, such as Russell's and Recanati's analyses, altogether or ( $i$ i) somehow blocking the steps from (20) to (21), (22) to (23), (9) to (10), and (5) to (6) without rejecting Russell's analysis of definite descriptions and Recanati's analysis of that-clauses. As we have seen above, it is very unclear how the latter could be achieved. Hence, if we accept the claim that there are non-trivial logical analyses, we are left with a puzzle. A complete solution to this puzzle does not only promise a better understanding of logical analyses, but, because of its similarity with Frege's puzzle, also of attitude ascriptions, such as (13) and (14).

Funding Open Access funding enabled and organized by Projekt DEAL.

Open Access This article is licensed under a Creative Commons Attribution 4.0 International License, which permits use, sharing, adaptation, distribution and reproduction in any medium or format, as long as you give appropriate credit to the original author(s) and the source, provide a link to the Creative Commons licence, and indicate if changes were made. The images or other third party material in this article are included in the article's Creative Commons licence, unless indicated otherwise in a credit line to the material. If material is not included in the article's Creative Commons licence and your intended use is not permitted by statutory regulation or exceeds the permitted use, you will need to obtain permission directly from the copyright holder. To view a copy of this licence, visit http://creativecommons.org/licenses/by/4.0/.

\section{References}

Braun, D. (1998). Understanding belief reports. Philosophical Review, 107, 555-95.

Crimmins, M., \& Perry, J. (1989). The prince and the phone booth: reporting puzzling beliefs. The Journal of Philosophy, 86, 685-711.

Crimmins, M. (1992). Talk about Beliefs. Cambridge: MIT Press.

Kaplan, D. (1968). Quantifying in. Synthese, 19, 178-214.

Kripke, S. (1979). A Puzzle about Belief. In A. Margalit (Ed.) Meaning and Use. Dordrecht: Reidel.

Kripke, S. (1980). Naming and Necessity. Oxford: Blackwell.

Lewis, D. (1979). Attitudes de dicto and de se. The Philosophical Review, 88, 513-43.

Neale, S. (1990). Descriptions. Cambridge: MIT Press Books.

Panaccio, C. (1996). Belief Sentences: Outline of a Nominalistic Approach. In M. Marion, \& R. S. Cohen (Eds.) Quebec Studies in the Philosophy of Science II (pp. 265-77). Dordrecht: Kluwer. 
Russell, B. (1905). On denoting. Mind, 14, 479-93.

Recanati, F. (2004). 'That'-clauses as existential quantifiers. Analysis, 64, 229-35.

Salmon, N. (1986). Frege's puzzle. Cambridge: MIT Press.

Salmon, N. (2011). A Note on Kripke's Puzzle about Belief. In A. Berger (Ed.) Saul Kripke (pp. 235-52). Cambridge: Cambridge University Press.

Strawson, P. F. (1950). On referring. Mind, 66, 385-89.

Publisher's Note Springer Nature remains neutral with regard to jurisdictional claims in published maps and institutional affiliations. 